\title{
CAREER COUNSELLING AS AN IMPORTANT COMPONENT THAT MAY BE OFFERED AS A SPECILIZATION FOR THE POSTGRADUATE STUDENTS PURSUING PROFESSIONAL COURSES IN SHILLONG, EAST KHASI HILLS DISTRICT, MEGHALAYA, INDIA TO ENHANCE TEACHER EDUCATION
}

\author{
Dr. S Maxwell Lyngdoh ${ }^{*}[\mathbb{Q}$ (iD \\ ${ }^{*}$ Adjunct Faculty, Martin Luther Christian University, Shillong, Meghalaya, India
}

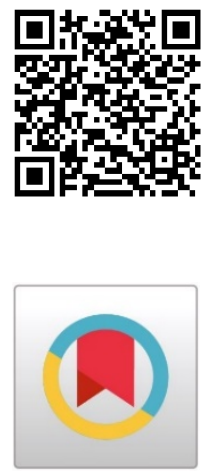

DOI: https://doi.org/10.29121/granthaalayah.v9.i2.2021.3386

Article Type: Research Article

Article Citation: Dr. S Maxwell Lyngdoh. (2021). CAREER COUNSELLING AS AN IMPORTANT COMPONENT THAT MAY BE OFFERED AS A SPECILIZATION FOR THE POSTGRADUATE STUDENTS PURSUING PROFESSIONAL COURSES IN SHILLONG, EAST KHASI HILLS DISTRICT, MEGHALAYA, INDIA TO ENHANCE TEACHER EDUCATION.

International Journal of Research GRANTHAALAYAH, 9(2), 138-148. https://doi.org/10.29121/granthaa layah.v9.i2.2021.3386

Received Date: 02 February 2021

Accepted Date: 26 February 2021

Keywords:

Career Counselling

Specilization

Postgraduate Students

\section{ABSTRACT}

Objective: To find out the need to offer career counselling as a specialization among the postgraduate students pursuing professional courses.

Methodology: A descriptive, cross sectional study design, collecting relevant quantitative and qualitative data from the respondents was conducted. Data on retrospective histories and experiences in career counselling was captured to link how career counselling is becoming an important aspect for career development and career decision making. In this study, a total of 100 students were studied.

Setting: Postgraduate students from MSc Counselling Psychology and Master of Social Work from Martin Luther Christian University, Shillong.

Results: Career counselling has led a student to be familiar with his/her interest and aptitudes, hence paving a way for them to make the right career choice. Career guidance has facilitated students to be focus with their career planning and in choosing relevant programmes during their course of study to help built their expertise. Career Counselling as an area should be enhanced, to create more professionals in the field.

Conclusion: There was a strong recommendation that proper career guidance and monitoring is the need of the hour, as students are either over exposed to career information or are not exposed to them at all. (198 words).

\section{INTRODUCTION}

Career Counselling is the professional guidance of the individual or a small group by use of standard psychological methods, such as case histories and data besides using various techniques like personal interviews and testing interest and aptitudes, etc. (Srivastava, 2007).

The National Education Policy 2020 stated that the "Policy envisions a comprehensive approach to transforming the quality and quantity of research in India. This, it says will include definitive shifts in school education to a more play and discovery-based style of learning - with a key emphasis on the scientific method and critical thinking, career

(C) 2021 The Author(s). This is an open access article distributed under the terms of the Creative Commons Attribution License, which permits unrestricted use, distribution, and reproduction in any medium, provided the original author and source are credited. 
Career Counselling as An Important Component That May Be Offered as A Specilization for the Postgraduate Students

Pursuing Professional Courses in Shillong, East Khasi Hills District, Meghalaya, India to Enhance Teacher Education

counselling in schools towards identifying student interests and talents". While this seems comforting, it may be mentioned that in the entire Policy, there is no specific mentioned of Career Counselling to be offered as a subject or any mention anywhere that Career Counsellors should be part and parcel of the education system in the country. The Oxford Dictionary (2021) defines Career as a "person's course or progress throughout his / her preoccupational, occupational and post-occupational life". Being a student, employer and pensioner, all become work related roles. The non-occupational roles of child, homemaker, citizen, etc. which run parallel to the work roles become part of one's career (Super 1983, 1990). If this definition is to be considered relevant, it will then suggest that a man needs guidance at every step of his life to help him grow personally and professionally. If one has to try to understand career counselling, it would actually include all counselling activities associated with career choice over a life span. In the career counselling process, all aspects of an individual needs (including family, work, personal concerns and leisure) are recognised as integral parts of career decision making and plan.

However, in a country like India, this understanding is yet to go a long process where career counselling as a concept was just heard over the last one decade and an individual's understanding of career counselling varies from one person to another and from one educational institution to the other. Thus, this calls for an immediate addressing of the issue and to be able to cater to this colossal requirement, the system needs to produce trained Career Counsellors in all the States of the country in order to be able to facilitate proper career guidance and counselling for the student community at large. This includes vocational and technical institutions to ensure that students join the right course / training while planning for their future.

\section{METHODOLOGY}

This research carried out a descriptive, cross sectional study design, collecting relevant quantitative and qualitative data, as well as capturing some retrospective histories and experiences of exposure to career counselling that the respondents had.

This research used a Purposive Sampling design. A purposive sample is a non-probability sample that is selected based on characteristics of a population and the objective of the study. Purposive sampling is also known as judgmental, selective, or subjective sampling. Suitable sampling methods and appropriate data gathering tools were then developed. At the first stage, Martin Luther Christian University, Shillong, East Khasi Hills District, Meghalaya was chosen for the study. The selection of this particular University is based on the criteria that they have been offering Career Counselling to all the students who are enrolled with them and this is part and parcel of the Admission process which is followed in the University since its inception in 2006. As the approach of MLCU towards educating their students is Holistic, Career counselling is being offered to the students in addition to their Academic program. The purpose is to assist them in their academic trajectory, enhance their abilities and orient the students on employability skills. The University believes that such initiatives will create more avenues for them to acquire meaningful employment, including self-employment, in both urban and rural setups. Career Counselling programs are arranged every semester to ease their transition from the time they are enrolled in the University till they face the world of work.

In the second stage, the Departments offering Professional Courses were chosen, whereby Career Counselling could be offered as a Specialization.

Table I A: Number of Respondents taken from various Departments offering Professional Courses

\begin{tabular}{|c|c|c|}
\hline Sl. No. & Name of the Courses & Number of Respondents \\
\hline & MA Peace \& Justice & 10 \\
\hline & MTh & 4 \\
\hline & MBA & 16 \\
\hline & MSc CP & 22 \\
\hline & MSW & 51 \\
\hline \multicolumn{2}{|c|}{ Total } & 103 \\
\hline
\end{tabular}




\section{Ethical Consideration}

All the respondents were briefed about the research study before they decided to be part of it. Informed consent was taken from all the respondents from the above-mentioned Departments. The consent of the Departments was also taken, seeking for prior approval before the questionnaires were given to them for filling.

\section{Major Findings}

The Findings in this research are presented as follows:

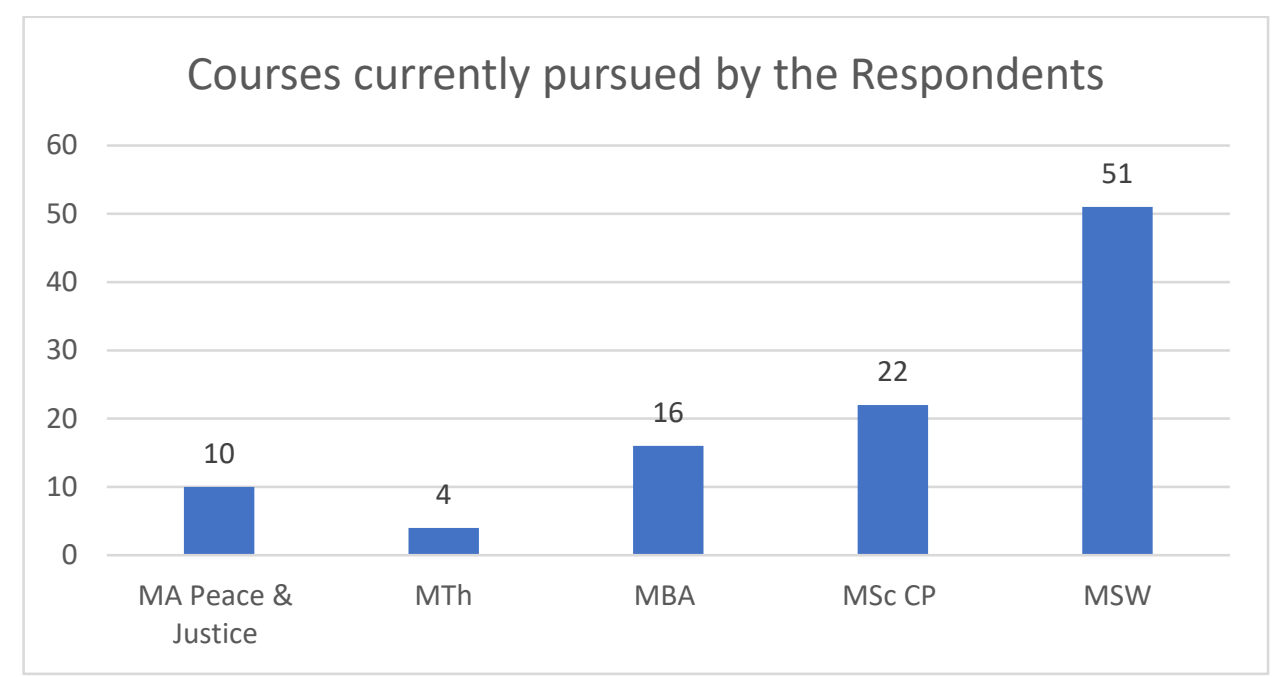

Figure I

The above Figure shows the total number of respondents taken from across the Post Graduate Courses whereby Career Counselling can be offered as a Specialization. The above Courses were specifically chosen because these are working Professionals who will directly be involved with the community, the students, youth and parents. A direct example is an MBA choosing Human Resource as a Specialization. If he/she opts Career Counselling as a second Specialization, then it would be easier for the individual to understand the employees better from the 'Career' aspect while monitoring their professional growth.

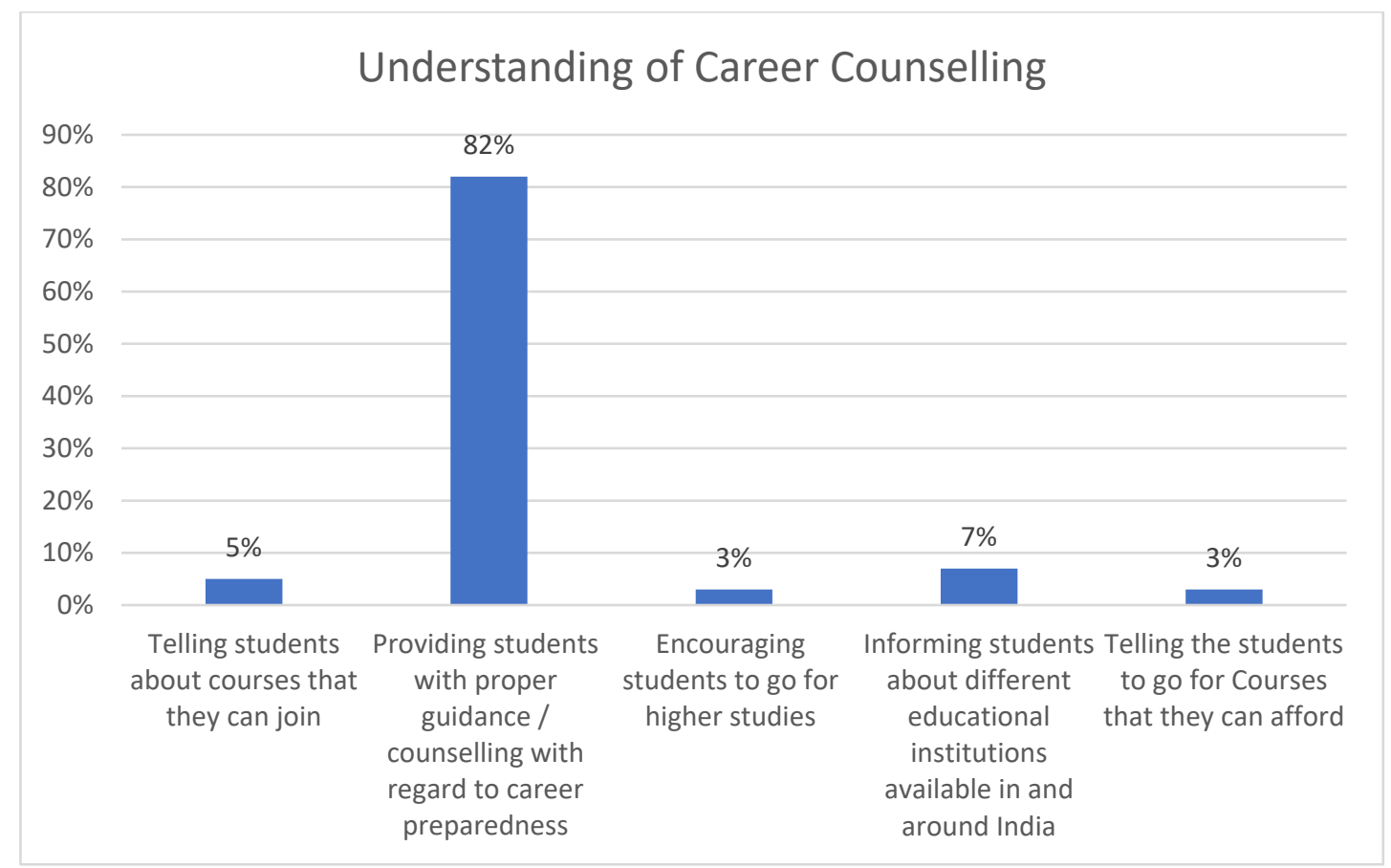

Figure II 
The above Figure portrays the understanding of the Participants on what 'Career Counselling' is all about. This implies that the respondents are familiar with the concept of career counselling and its importance where by $82 \%$ of them has rightly chosen the response from the given options.

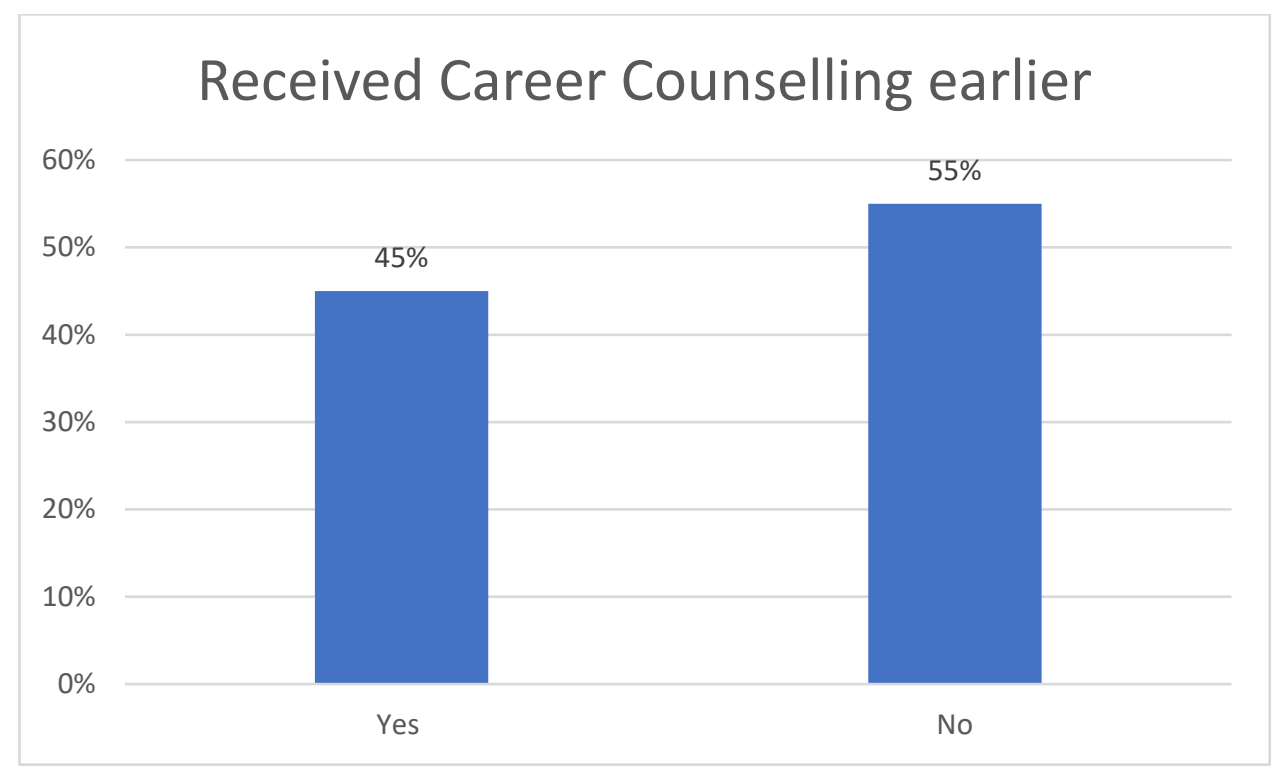

Figure III

The above Figure shows the total number of respondents who have received Career Counselling prior to this survey. $55 \%$ of the respondents have received career guidance at some point or the other, while the remaining $45 \%$ have not received any career counselling at all.

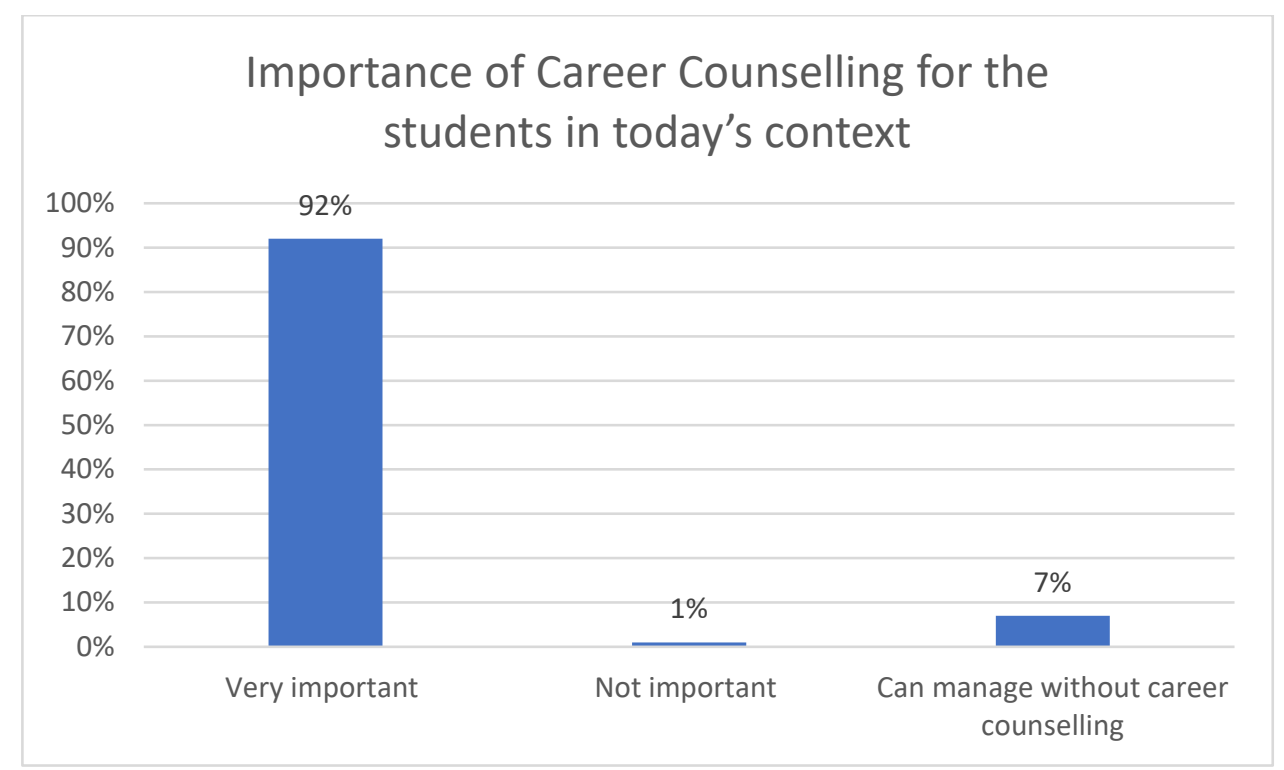

Figure IV

The above Figure shows the understanding of the respondents (currently students) on the importance of Career Counselling for the student's community at large. This response would have come because of the realization that they require career guidance and counselling in their day-to-day encounter with difficult decision making, especially when it comes to their future career plans. The high number of responses for marking career counselling as very important would have also come from those respondents who had attended such sessions earlier and in turn, the career guidance have helped them in taking right career decision. 


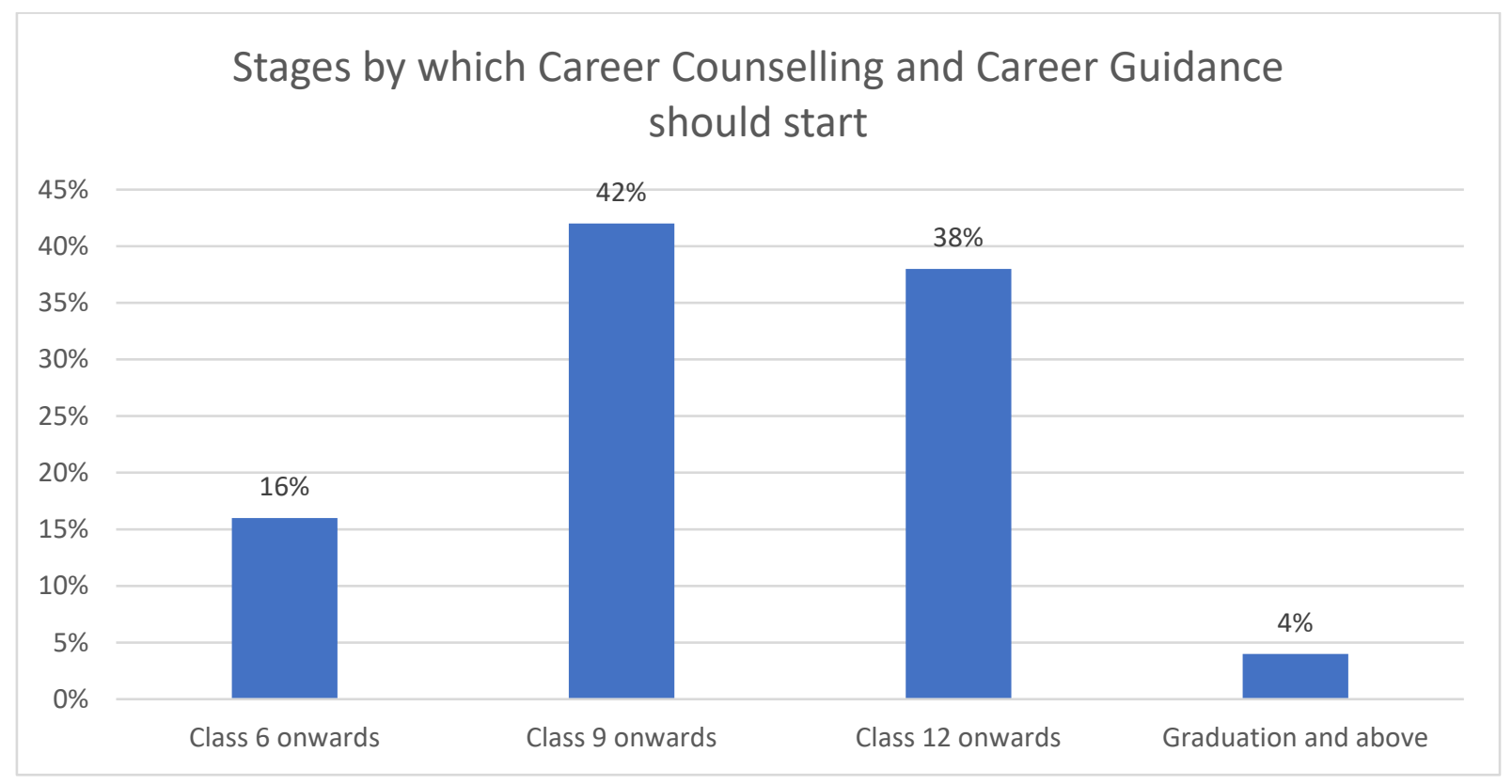

Figure V

The above Figure reflects that the respondents would have done a little bit of introspection before responding to the above question. A high percentage of the respondents agree that Career Counselling should start as early as Class IX. This is the age where students and parents start thinking / discussing about their future career plans, what Course to pursue after Class XII and so on.

$38 \%$ of the respondents which is the second highest response opine that Career Counselling should start from Class XII onwards. This is very crucial because at this point in time, major decisions are being taken as their career path is being diverted to a larger extend.

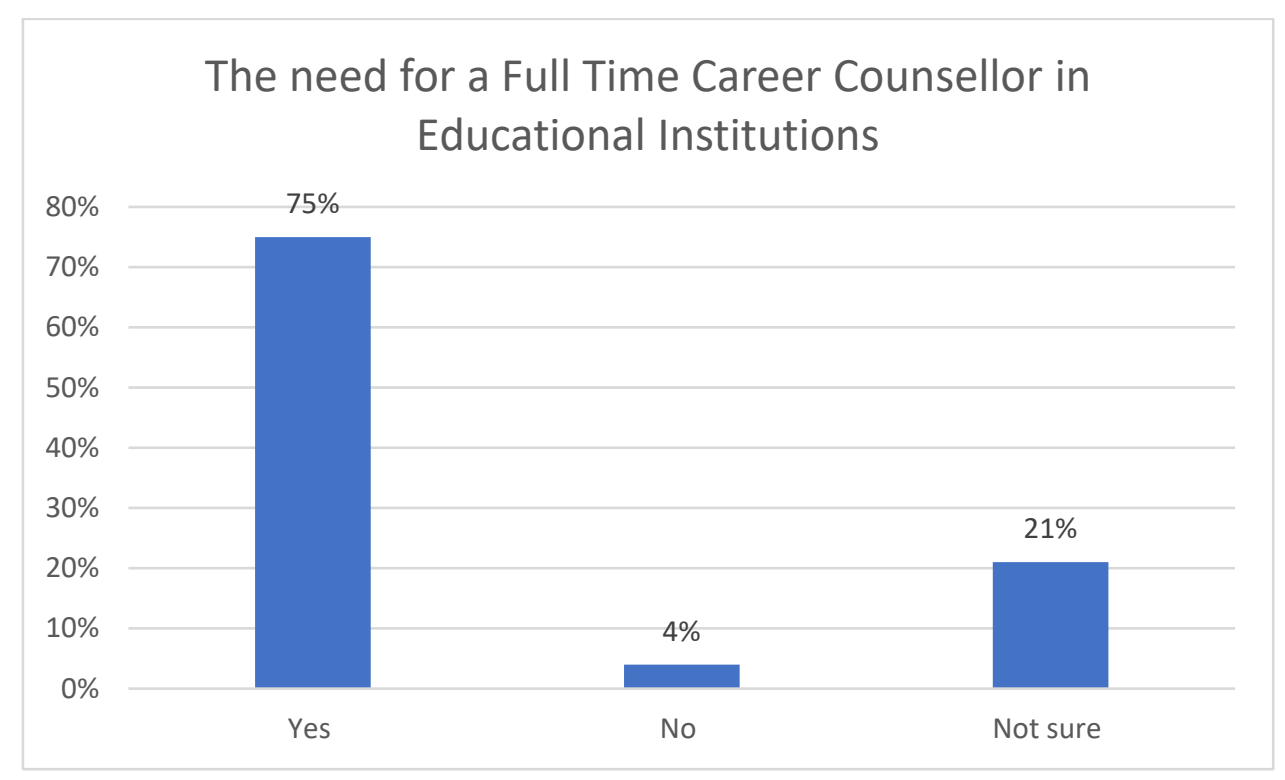

Figure VI

The above Figure shows responses up to 75\% firmly agreeing that all Educational Institutions (Schools, Colleges, Universities, and Vocational Training Centers) need to have a full time Career Counsellor which can facilitate proper guidance to students at any point of their life when they are confuse with career related matters and need expert guidance. 
Career Counselling as An Important Component That May Be Offered as A Specilization for the Postgraduate Students Pursuing Professional Courses in Shillong, East Khasi Hills District, Meghalaya, India to Enhance Teacher Education

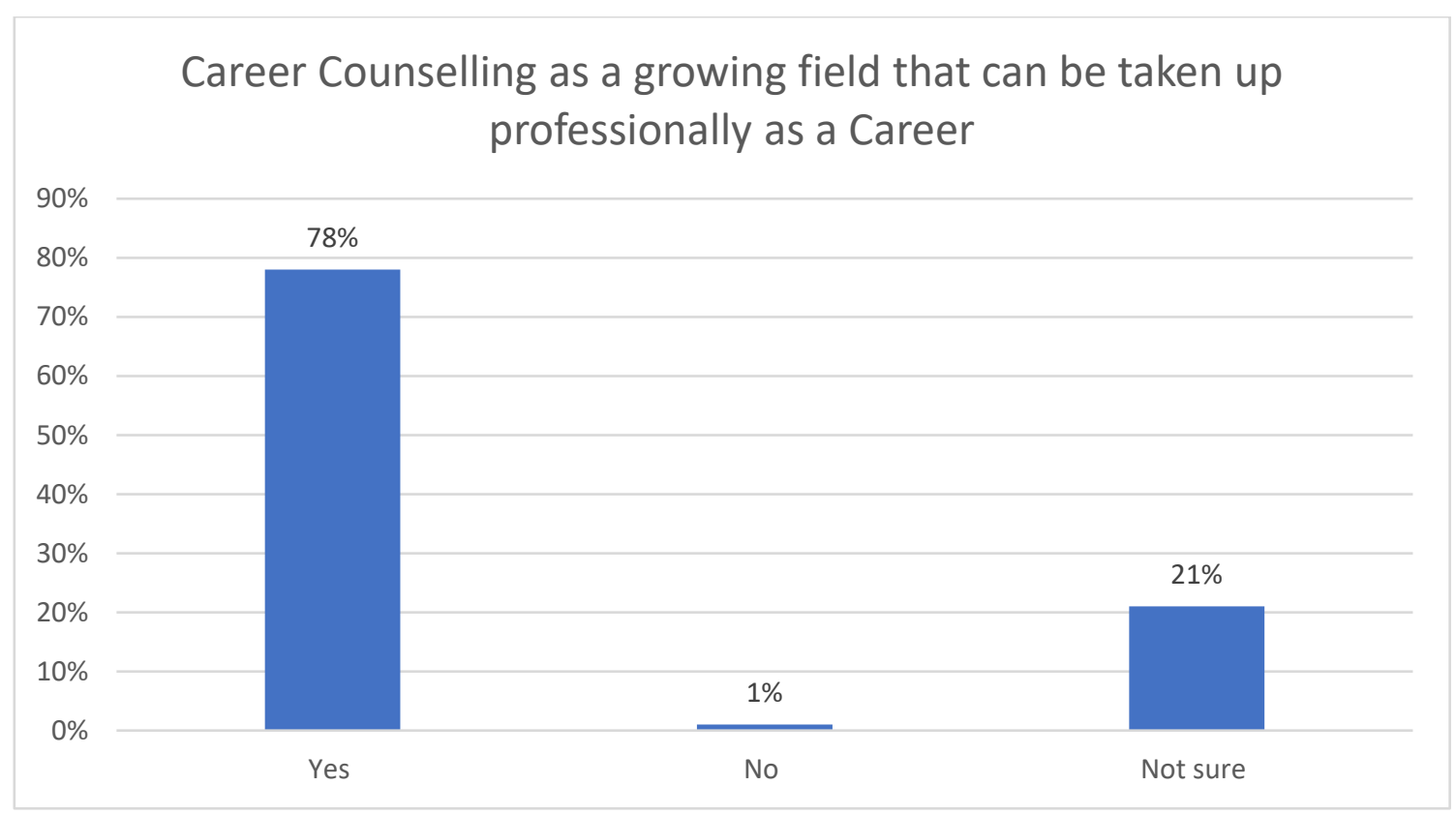

Figure VII

The above Figure show that a major portion of the responses were in agreement that Career Counselling is a growing field. This implies that there is a high demand for such human resources and professionals to fill in the lacuna. This means to suggest that more individuals are required to be trained as experts to be equipped to handle the Career Counselling in all educational institutions be it at the rural or urban setup.

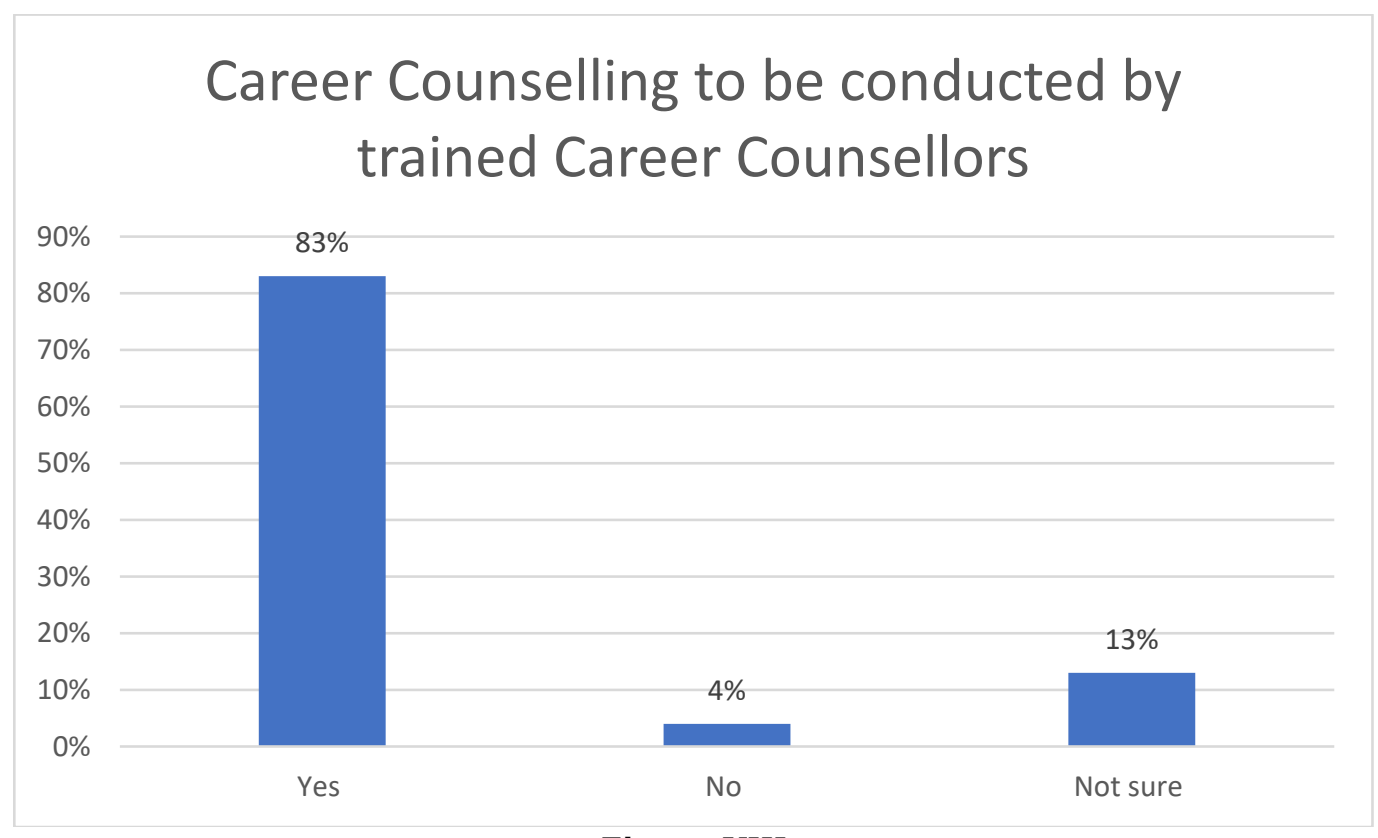

Figure VIII

The above Figure implies that as much as Career Counselling forms an important component of the whole package in facilitating proper guidance for the students, the Figure also suggest that such guidance should be provided by trained Career Counsellors, thereby avoiding any wrong approach in understanding the students' potentials and competencies and in providing them with the right career information which is relevant and applicable to the local context. 


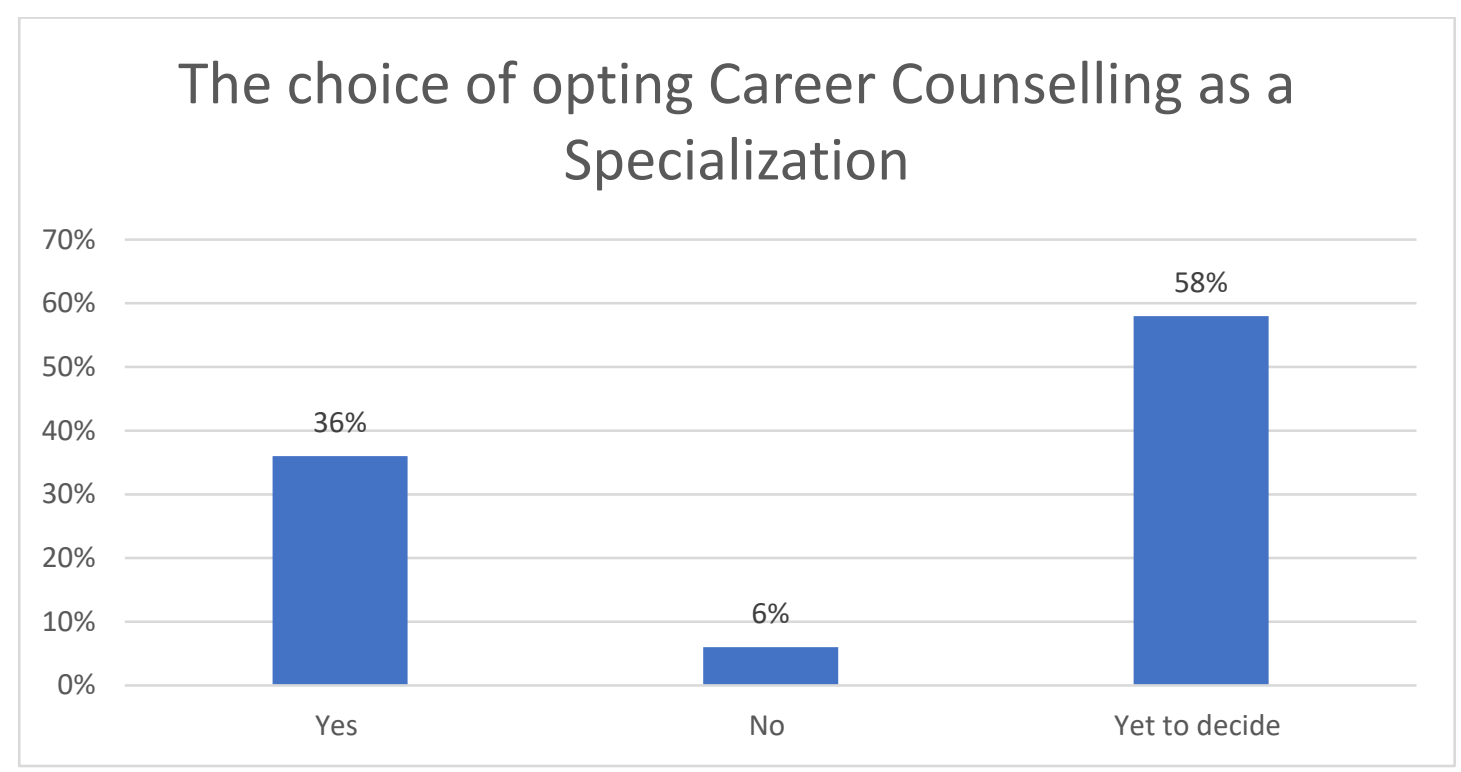

Figure IX

The above Figure shows the data of the respondents who would like to take up Career Counselling as a Specialization. About 58\% of the respondents are yet to decide if they would like to take up this specialization. This suggests that the respondents are pretty serious about Career Counselling which is the need of the hour and they would like to it forward by pursing a Course on it.

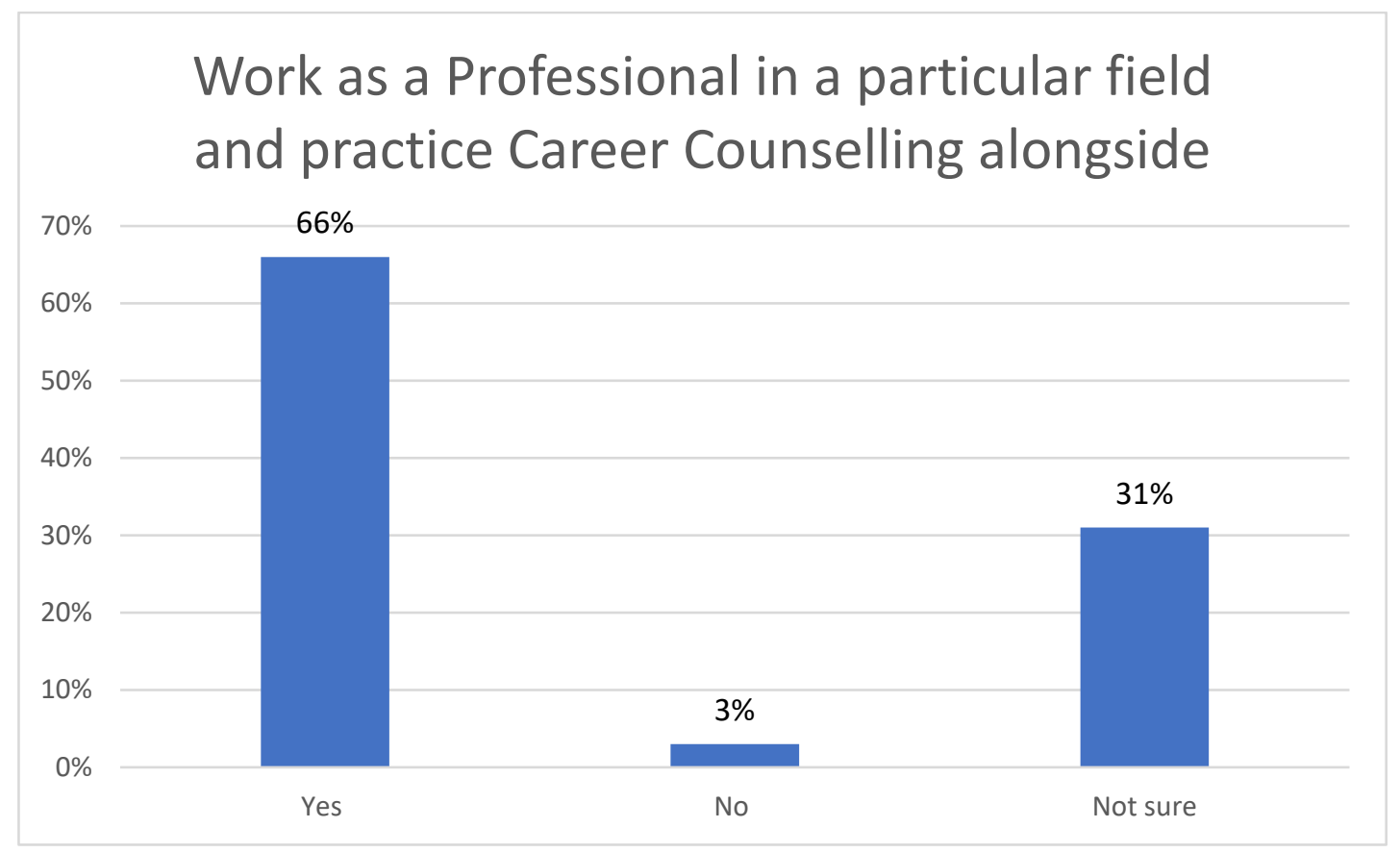

Figure X

The above Figure shows that a big percentage of the respondents would like to be involved in Career Counselling as a service to the students besides being a Professional in their respective fields. The above response came from students pursuing Courses like Master of Arts in Peace and Justice, Master in Theology, Master in Business Administration, Master of Science in Counselling Psychology and Master in Social Work. 


\section{Awareness about pursuing higher studies (Certificate, Diploma, MPhil and PhD) in Career Counselling}

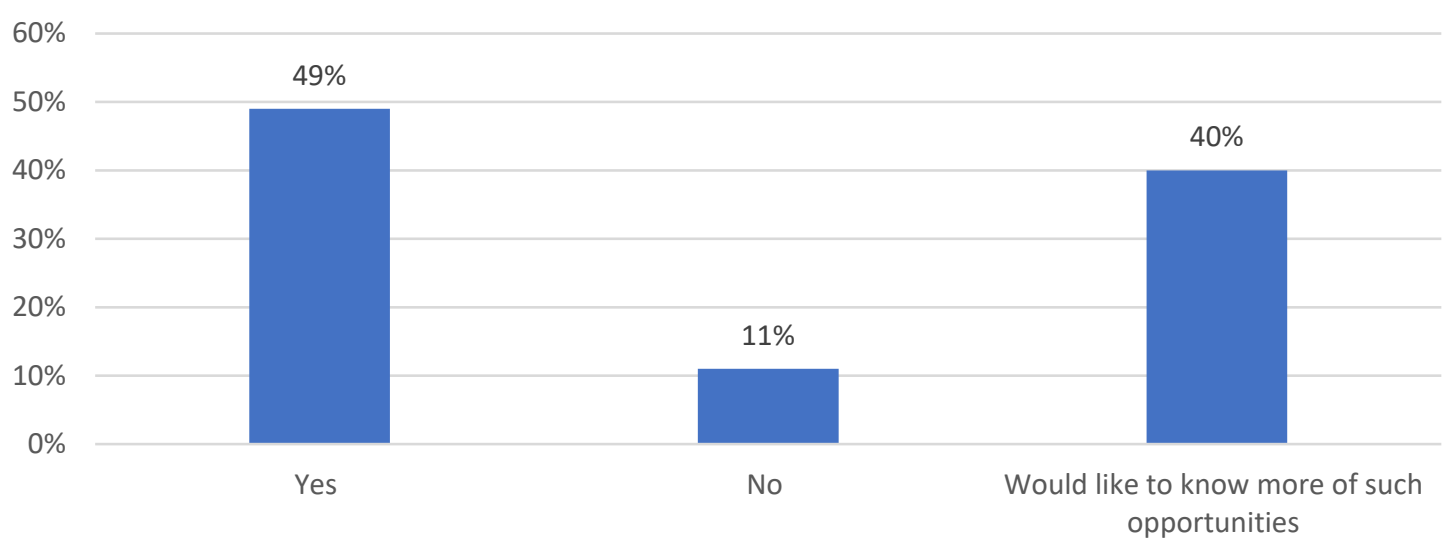

Figure XI

The above Figure shows the number of respondents who are familiar about Higher Studies in relation to Career Counselling. While $49 \%$ are familiar about such opportunities, $40 \%$ others suggested that they would like to know more about higher studies which can be pursued in this field.

\section{Produce in verbatim}

Table I B: Sub Themes

\begin{tabular}{|c|c|c|c|}
\hline $\begin{array}{l}\text { Sl. } \\
\text { No. }\end{array}$ & $\begin{array}{l}\text { Topics under } \\
\text { Jobs: }\end{array}$ & $\begin{array}{l}\text { Sl. } \\
\text { No. }\end{array}$ & $\begin{array}{c}\text { Topics under } \\
\text { Self-Understanding: }\end{array}$ \\
\hline & Job Trends & 1. & $\begin{array}{l}\text { Knowing the scope (merits and demerits) of one's } \\
\text { own course }\end{array}$ \\
\hline & Awareness on Skills required for a Job & 2. & Developing passion as work \\
\hline & $\begin{array}{l}\text { Techniques of inculcating to different job } \\
\text { environment }\end{array}$ & 3. & Regarding how to achieve their aim \\
\hline & For gaining work experience & 4. & How to select their interest goals \\
\hline & Job Description & 5. & It helps us to decide whatever we need \\
\hline & Job and their ranking & 6. & $\begin{array}{l}\text { Knowing the benefits before choosing a } \\
\text { specialization }\end{array}$ \\
\hline & $\begin{array}{l}\text { Availability of job opportunities after } \\
\text { studies }\end{array}$ & 7. & $\begin{array}{l}\text { Understanding Self- the impact of one's career in } \\
\text { society }\end{array}$ \\
\hline & Skills Development & 8. & Self-awareness \\
\hline & Youth Employment & 9. & The changing dynamics of today's Profession \\
\hline & Potential Job openings & 10. & $\begin{array}{c}\text { To opt for Career / Course which one feels is good } \\
\text { at }\end{array}$ \\
\hline
\end{tabular}

Table I C: Sub Themes

\begin{tabular}{|c|c|c|c|}
\hline $\begin{array}{c}\text { Sl. } \\
\text { No. }\end{array}$ & $\begin{array}{c}\text { Topics under } \\
\text { Counselling: }\end{array}$ & $\begin{array}{c}\text { Sl. } \\
\text { No. }\end{array}$ & $\begin{array}{c}\text { Topics under } \\
\text { Career Information: }\end{array}$ \\
\hline 1. & Motivation to workers & 1. & Choosing right Institutions for further studies \\
\hline 2. & Learning Styles & 2. & $\begin{array}{c}\text { Prepare students for the outside world/ further } \\
\text { studies }\end{array}$ \\
\hline
\end{tabular}


Dr. S Maxwell Lyngdoh

\begin{tabular}{|c|c|c|c|}
\hline 3. & Types of Personality & 3. & $\begin{array}{c}\text { Awareness about different types of Career } \\
\text { Choices }\end{array}$ \\
\hline 4. & Manual of Career Counselling & 4. & Give more information about Vocational Courses \\
\hline 5. & Career Reference Record & 5. & Different types of workplace available \\
\hline 6. & $\begin{array}{c}\text { Understanding the field of interest of the } \\
\text { students and the reality }\end{array}$ & 6. & Preparation for various Competition Exams \\
\hline 7. & Dignity of Labour & 7. & Entrepreneurship Development \\
\hline 8. & $\begin{array}{c}\text { Directing a student who have a talent } \\
\text { towards certain activity(s). }\end{array}$ & 8. & Career Development \\
\hline 9. & Peer Pressure & 9. & $\begin{array}{c}\text { International / Governmental / Non- } \\
\text { Governmental Organizations }\end{array}$ \\
\hline 10 & Behaviour of individuals towards a Career & 10. & $\begin{array}{c}\text { Opportunities and Scholarships available at } \\
\text { colleges in India / Abroad. }\end{array}$ \\
\hline
\end{tabular}

\section{DISCUSSION}

The Oxford English Dictionary (2021) defines career as a "person" or progress throughout his / her preoccupational, occupational and post-occupational life". Being a student, employer and pensioner, all become work related roles. The non-occupational roles of child, homemaker, citizen etc which run parallel to the work roles become a part of one's career (Super 1983, 1990). However, while trying to understand the concept of career development, the American Counselling Association define career development as "the total constellation of psychological, sociological, educational, physical, economic, and chance factors that combine to influence the nature and significance (Engels, 1994).

In simple terms, career counselling includes all counselling activities associated with career choice over a lifespan. In the career counselling process, all aspects of an individual needs (including family, work, personal concerns and leisure) are recognised as integral part of career decision making and plan. This seems to have been understood clearly by the students (respondents) in Figure II where 82\% agreed that career counselling leads to providing students with proper guidance and counselling with regard to career preparedness which incapsulates aspects of individual needs.

The foundation of career counselling was initially based on the principle of individual differences in terms of assets and strengths. Measures of individual traits were the primary focus of early career counselling and the major goal was to match an individual's assets and strengths with job requirements (Picchioni and Bonl, 1983). 92\% of the respondents (as shown in Figure IV) agreed that career counselling for the students in today's context is very important. This response seemed to have come with exposure and experiences that students went through in their academic life. This is one reason why career counselling is essential for everyone at various stages. It can be at school level when he / she has to decide his / her major subjects in college; or the individual at college level, has to decide on his / her further academic study, professional study or while seeking a job; or the individual at mid-career stage when he / she decides whether to continue or change his or her discipline in the same organization or change to another organization etc. This was confirmed when $42 \%$ of the respondents (Figure V) agreed that career counselling should start from Class 9 onwards, while 38\% of the respondents suggested that career counselling should start from Class 12 onwards.

While career counselling is considered as highly important in today's scenario, career counsellors' function as therapeutic agents who help people to integrate their various life and vocational roles such as maximum opportunities for their clients, interpreting the relationship between training with new career paths, providing clients a support system by which s/he can acquire insight into their own stereotypes and irrational beliefs that are hindering their risks taking and mobility and mentoring which involves coaching, providing advice and feedback about career-related tasks. Figure VI showcase the data whereby $75 \%$ of the respondents strongly agreed that all educational institutions (schools, colleges, universities, vocational training centers) need to have a full time Career Counsellor which can facilitate proper guidance to students at any point of their life when they are confuse with career related matters and need expert guidance. 
Career Counselling as An Important Component That May Be Offered as A Specilization for the Postgraduate Students

Pursuing Professional Courses in Shillong, East Khasi Hills District, Meghalaya, India to Enhance Teacher Education

Career Counsellors must have a good understanding of designing and implementing organizational career support programs and activities. They should be competent to provide individual and group counselling, training and management of career services. This seems to suggest that the third suggestion that is in line with the above findings is to have an expert career counsellor trained professionally for this purpose. Figure VIII portrays that $83 \%$ of the respondents agreed that career counselling should be provided by trained career counsellors to ensure that the students are able to get the right career information and guidance which is relevant and applicable to the local context.

The respondents, when being asked about the topics (Table I (B) Sub Themes which they feel is very relevant and should be covered during career counselling sessions have mentioned many sub-topics categorise under four major topics. They are Jobs, Self-understanding, Counselling and Career Information. This implies that career counselling covers a colossal spectrum of topics besides the usual topics that are being covered. Figure VII portrays a clear understanding that the respondents have got in relation to career counselling. They agreed that career counselling is a growing field and there is a high demand for such human resources and professionals to fill in the lacuna. This means to suggest that more individuals are required to be trained as experts to be equipped to handle the career counselling in all educational institutions be it at the rural or urban setup.

\section{CONCLUSION}

To conclude, it may be stated that career counselling is an area that is highly required to be incorporated into the education system of the country. The respondents not only have expressed their knowledge about the need for career counselling but have also showed their keenness to opt it as a specialization (Figure IX). The respondents are also aware that it can be pursued as higher studies like a Certificate Course, Diploma, MPhil and PhD (Figure XI). What is over whelming to notice is the fact that a high percentage of the respondents pursuing professional courses like Master of Arts in Peace and Justice, Master in Theology, Master in Business Administration, Master of Science in Counselling Psychology and Master in Social Work are keen to be involved in Career Counselling as a service to the students besides being a Professional in their respective fields.

The initiative to offer career counselling services to students is a must and it should be made mandatory at all levels of educational institutions, both at the rural and urban setups. It may be kept in mind that the approach of career counselling in urban institutions will very much vary from that in the rural. While the career counselling in the urban areas will be focused more on job information, future career path, career planning and career decision making, career counselling in rural areas will be more towards entrepreneurship and local livelihoods. Helping the students to identify natural resources and utilizing them for their livelihood may be the apt guidance that they may need to start with.

Lastly, it may be suggested that career counselling as a Course must be introduced in all central, state and private universities for teachers to opt for, while at the same time practicing their teaching profession. This will facilitate to raise the required resources of career counsellors in a developing country like India where education is still one of the major concerns that needs constant addressing and monitoring.

\section{SOURCES OF FUNDING}

This research received no specific grant from any funding agency in the public, commercial, or not-for-profit sectors.

\section{CONFLICT OF INTEREST}

The author have declared that no competing interests exist.

\section{ACKNOWLEDGMENT}

None. 


\section{REFERENCES}

[1] Bhansali, A. (2019). Academic Vs. Professional Degree After Class 12th: Which One is Better?, MINDLER Blog, Retrieved on November 26, 2020 at 15:09 pm https://www.mindler.com/blog/academic-vs-professionaldegree/\#: :text=A\%20professional\%20course\%20is\%20one,you\%20'job\%2Dready

[2] Engels DW, Harris HL. Career Development: A Vital Part of Contemporary Education. NASSP Bulletin. 1999; 83 (603): 70 - 76. Doi :10.1177 / 019263659908360311

[3] Final Draft Meghalaya State Education Policy, Government of Meghalaya Department of Education, (2018). Retrieved on November 13, 2020 at 09:13 am http://www.megeducation.gov.in/circulars/2018/Final-Draftof-Education-Policy_2018.pdf

[4] Koshi, L. (2019). Building an ecosystem for career counsellors in India: Meet edutech startup Mindler, The News Minute, Retrieved on December 10, 2020 at 04:04 pm https://www.thenewsminute.com/article/building-ecosystem-career-counsellors-india-meet-edutechstartup-mindler104206\#: :text=Career\%20counselling\%20in\%20India\%20is,student\%20to\%20school\%20counsellor\%2 0ratio.

[5] Lyngdoh, S.M. (2020). "National Education Policy 2020: Emphasizing Career Guidance" https://www.thenativetribe.org/book/nep-2020/nep-2020-v2 ORCID iD 0000-0001-9307-1139

[6] Martin Luther Christian University, Dongktieh, Block - 1, Nongrah, Shillong 793006 Meghalaya, Retrieved on October 23, 2020 at 13:09 pm https://www.mlcuniv.in/about-us/mlcu-administration/

[7] National Education Policy (NEP) 2020. Retrieved on December 10, 2020, at 11:05 pm https://www.education.gov.in/sites/upload_files/mhrd/files/NEP_Final_English_0.pdf

[8] Oxford University Press. (C) 2021 Lexico.com, Retrieved on November 30, 2020 at 09:00 am https://www.lexico.com/definition/career

[9] Picchioni, A. P., \& Bonk, E. C. (1983). A comprehensive history of guidance in the United States. Austin, TX: Texas Personnel and Guidance Association.

[10] Srivastava, S. K. (2007). Career Counselling. Saujanya Publications, New Delhi, Retrieved on December 18, 2020 at $18: 00 \mathrm{pm}$

[11] Super, D. E. (1990). A life-span, life-space approach to career development. In D. Brown and L. Brooks (Eds.) Career choice and development: Applying contemporary theories to practice, 2nd ed., (pp. 197-261). San Francisco, CA: Jossey-Bass, Inc. Retrieved on January 12, 2021 at 18:05 pm

[12] Website of East Khasi Hills District, Meghalaya, Retrieved on October 12, 2020 at 08:09 am https://eastkhasihills.gov.in/ 